\title{
The history of basilar artery occlusion: when art aids science
}

\author{
História da oclusão da artéria basilar: quando a arte auxilia a ciência \\ Francisco Antunes Dias', Daniel Giansante Abud², Octavio Marques Pontes-Neto ${ }^{1}$
}

\begin{abstract}
Basilar artery occlusion (BAO) ischemic stroke is a relatively rare condition with high morbidity and mortality rates. To date, the best acute reperfusion therapy for BAO has still not been established, mainly due to the lack of randomized controlled trials in this field. In this article, we review the history of BAO diagnosis and treatment, and the impact of modern technological resources on the clinical evolution and prognosis of BAO over time. Furthermore, we describe historical events and nonmedical literature descriptions related to BAO. We conclude that BAO is a singular example of how art may help medical sciences with accurate descriptions of medical conditions.
\end{abstract}

Keywords: stroke; basilar artery; history.

\section{RESUMO}

O acidente vascular cerebral isquêmico secundário à oclusão aguda da basilar (OAB) é uma condição relativamente rara, que cursa com elevada morbimortalidade. Até o momento atual, a melhor estratégia de recanalização arterial na fase aguda da OAB não está definida, principalmente pela carência de ensaios clínicos randomizados e controlados neste contexto. Neste artigo, revisamos aspectos históricos do diagnóstico e do tratamento desta condição, assim como o impacto do avanço tecnológico na evolução clínica e prognóstico desta condição. Ademais, descrevemos fatos históricos e a literatura fictícia relacionados à OAB. Concluímos que a OAB é um exemplo peculiar de como a arte pode auxiliar a medicina na descrição acurada de condições médicas.

Palavras-chave: acidente vascular cerebral; artéria basilar; história.

Acute basilar artery occlusion (BAO) is a relatively rare condition that usually leads to severe neurological deficits, such as coma and locked-in syndrome, and it is linked to high morbidity and mortality rates ${ }^{1,2}$.

We aimed to review the preliminary historical descriptions of $\mathrm{BAO}$, and the evolution of its diagnosis and treatment over time. We also highlight how BAO history is related to the arts.

\section{THE HISTORY OF BASILAR ARTERY OCCLUSION}

The first clinical description of a BAO patient was possibly made by the Scottish physician John Abercrombie in $1828^{3}$. He described an 18-year-old man diagnosed through necropsy. At that time, the etiology was suspected to be an "ossification" of the basilar artery.

After Virchow's notable studies in thromboembolism, published in 1847 and 1856, the relationship between cerebral focal ischemia and arterial occlusion was suggested, and $\mathrm{BAO}$ was then properly attributed to thromboembolic events, mainly from atherosclerosis. ${ }^{3}$ In 1868, Hayem published a detailed description of $\mathrm{BAO}$ symptoms and signals, through clinical-pathological correlation in five patients ${ }^{3,4}$.

In the $20^{\text {th }}$ century, before the $1950 \mathrm{~s}$, a BAO diagnosis was restricted to postmortem studies. Until the 1980s, a BAO was still linked to a $100 \%$ lethality rate ${ }^{5}$. Indeed, at that time, only BAO patients with persistent severe neurological deficits were submitted for cerebral angiography, through direct cervical access. This diagnostic method was not performed routinely in posterior circulation stroke patients, due to the inherent risks of the procedure, and also because no effective treatment could be offered for BAO patients. This practice remained common until the mid-1970s, even after Seldinger's description of a new technique in $1953^{6}$, in which the angiography could be performed through femoral artery catheterization. Therefore, there was a clear selection bias for the BAO diagnosis.

\footnotetext{
${ }^{1}$ Universidade de São Paulo, Faculdade de Medicina de Ribeirão Preto, Hospital das Clínicas, Departamento de Neurociências e Ciências do Comportamento, Ribeirão Preto SP, Brasil;

${ }^{2}$ Universidade de São Paulo, Faculdade de Medicina de Ribeirão Preto, Hospital das Clínicas, Departamento de Medicina Interna, Divisão de Radiologia, Ribeirão Preto SP, Brasil.

Correspondence: Francisco Antunes Dias; Unidade de Emergência - Hospital das Clínicas da Faculdade de Medicina de Ribeirão Preto da Universidade de São Paulo (HCFMRP/USP); Rua Bernardino de Campos 1000, Centro;14015-130 Ribeirão Preto SP, Brasil. E-mail: franciscodias.neuro@usp.br

Support: Dr. Pontes-Neto received research support from Conselho Nacional de Desenvolvimento Científico e Tecnológico (CNPq: 402388/2013-5); Fundação de Amparo à Pesquisa do Estado de São Paulo (FAPESP: 2016/15236-8) and CAPES (402388/2013-5).

Conflict of interest: There is no conflict of interest to declare.

Received 01 November 2017; Received in final form 05 January 2018; Accepted 06 February 2018.
} 
From the 1980s, with the greater availability of CT scans and increasing use of the Seldinger's technique, the diagnosis of BAO substantially improved. More recently, with the advent of noninvasive neuroimaging, such as transcranial Doppler sonography, CT angiography and magnetic resonance angiography, identification of intracranial occlusions has become widely feasible. Since then, it has become clear that BAO actually has a wide variability of clinical presentations and functional outcomes. However, severely impaired patients remain predominant. Indeed, recent studies have demonstrated low functional independence rates when patients are not treated with acute reperfusion therapies or when adequate recanalization of the basilar artery is not obtained ${ }^{1,2}$. Current acute BAO reperfusion strategies are not very different from other large artery occlusion acute ischemic strokes, despite a lack of good quality evidence for BAO strokes.

\section{BASILAR ARTERY OCCLUSION AND FICTIONAL LITERATURE}

Locked-in syndrome, coined by Plum and Posner in 1966, is a rare condition caused by an insult to the ventral pons ${ }^{7}$. Its main characteristics are complete paralysis of the body, with preservation of consciousness. Patients are unable to speak, but retain vertical eye movements, facilitating nonverbal communication. Basilar artery occlusion infarcts are by far the most common cause of the syndrome, but hemorrhage, trauma and demyelinating lesions are also reported.

The first description of the locked-in syndrome is in Alexandre Dumas' famous novel The Count of Monte Cristo, written in $1844^{8}$, where the author describes Monsieur Noirtier de Villefort, an old disabled man. In a very eloquent way, he describes Monsieur Villefort as follows: “[...] when the soul is trapped in a body that no longer obeys its commands". This character, although completely paralyzed, was able to communicate with people through blinking his eyes. Dumas described it:

"Sight and hearing were the only senses remaining, and they, like two solitary sparks, remained to animate the miserable body which seemed fit for nothing but the grave; it was only, however, by means of one of these senses, that he could reveal the thoughts and feelings that still occupied his mind...”
In 1867, Émile Zola, in his novel entitled Thérèse Raquin, described a paralyzed woman, who had the capacity of communicate with only her eyes. ${ }^{7}$ It was only in 1875 , when Darolles described the first reference to locked-in syndrome in medical literature, followed many years later by the brilliant descriptions by Zola and Dumas?

More recently, in 1995, Jean-Dominique Bauby, a 43-year-old French journalist, suffered a BAO stroke. After lapsing into a coma, he woke up with locked-in syndrome. Despite that, by blinking his left eye, he was able to plan and edit a book containing his memoirs, entitled The diving bell and the butterfly, published in $1997^{\circ}$, and a bestseller in French literature. He described his thoughts and feelings of being incapacitated by such a terrible condition:

"Until then, I had never heard of the brainstem. That day I discovered this masterpiece - on our on-board computer - a mandatory passage between the brain and nerve endings, when a stroke brought me down. Previously, they called it "congestion" and people simply died. The progress of reanimation techniques refined the punishment. We escaped but, "graced" by what Anglo-Saxon medicine calls locked-in syndrome: paralyzed from head to toe, the patient keeps his spirit intact, using the blinking of his left eyelid as the only means of communication."

According to him, immediately after his coma he could think, hear and smell, but with difficulty, compromising his communication with the external environment, and feeling an extreme sense of imprisonment. He referred to this phase as being stuck in a diving suit. In a second period, after recovering the capacity to communicate with others, and consequently change the world around him, Bauby referred to the birth of a butterfly, acquiring some liberty and independence. His book was made into a movie, which has won several international awards. The author, unfortunately, passed away about a year after his stroke.

\section{CONCLUSIONS}

BAO is a rare condition with a high mortality rate. Its diagnosis and treatment has progressed over time, parallel to the evolution of technology. BAO is a remarkable example of how art may help advance science with accurate descriptions of some medical conditions.

\section{References}

1. Mattle HP, Arnold M, Lindsberg PJ, Schonewille WJ, Schroth G. Basilar artery occlusion. Lancet Neurol. 2011 Nov;10:1002-14. https://doi.org/10.1016/S1474-4422(11)70229-0

2. Dias FA, Alessio-Alves FF, Castro-Afonso LH, Cougo PT, Barreira

CMA, Camilo MR et al. Clinical outcomes of patients with

acute basilar artery occlusion in Brazil: an observational
study.J Stroke Cerebrovasc Dis. 2017 Oct;26(10):2191-8.

https://doi.org/10.1016/j.jstrokecerebrovasdis.2017.04.043

3. Kompanje EJ, Walgaard C, Groot YJ, Stevens M.

Historical sources of basilar artery occlusion.

Neurology. 2011 Apr;76(17):1520-3.

https://doi.com/10.1212/WNL.0b013e318217e755 
Hayem MG. Sur la thrombose par artérite du

tronc basilaire comme cause du mort rapide. Arch

Physiol Norm Pathol. 1868;1:270-89.

5. Biemond A. Thrombosis of the basilar artery and the vascularisation of the brainstem. Brain 1951;74(3):300-17.

6. Seldinger SI. Catheter replacement of the needle in percutaneous arteriography. Acta Radiol. 1953 May;39(5):368-76.
7. Laureys S, Pellas F, Van Eeckhout P, Ghorbel S, Schnakers C, Perrin E, Berré $J$ et al. The locked-in syndrome: what is it like to be conscious but paralyzed and voiceless? Prog Brain Res. 2005;150:495-511. https://doi.org/10.1016/S0079-6123(05)50034-7

8. Williams AN. Cerebrovascular disease in Dumas' the count of Monte Cristo. J R Soc Med. 2003 Aug;96(8):412-4.

9. Bauby JD. The diving bell and the butterfly. London: Fourth Estate; 1997. 